\title{
特集 熱可塑性エラストマー
}
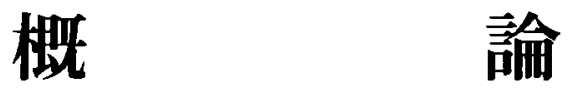

小松 公 栄*

\section{1.はじめに}

景気の回復がきざしている昨今であるが，数次にわた る石油ショックの影響は深刻であり，いぜんとして低成 長時代が続いている，我が国の素材産業を取りまく環境 は綮しく高分子化学工業, ゴム工業も例外でない.

ゴムやプラスチックの消費量が伸びないのに対し，熱 可塑性エラストマー（Thermoplastic Elastomer，以下 TPE)が毎年 $10 \%$ 以上伸長していることは特筆される。 低成長時代では省エネルギー，省資源対策が重要であ り，実用可能な手段を用いて改善する Soft Energy Path")のようなソフト技術及び材料が求められている.

一方, 成熟型消費社会では生活の高度化や多様化が進み 先進工業国の消費拡大も望まれないので，ューザの選択 基準は緟しくなり，素材産業は量から質への転換をせま られ高付加価值化が必然的となっている5). TPEの伸長 は上記の今日的背景に基つくくのであり，加硫ゴム分 野, プラスチック分野, 高付加価値分野人の進出が著し い，本誌が今回 TPE の特集を企画したことは，極めて 時期を得たものであり，本稿では全体的傾向を概説す る.

\section{TPE - 般}

\subsection{TPEの分類}

TPE は常温では加硫ゴムの性質を示すが，高温で可 塑化されてプラスチック加工機で成形できる高分子材料 と定義される3)，TPEには分子中に，エントロピー弾性 を有するゴム成分 (soft segment) と塑性変形を防止する ための分子拘束成分 (hard segment)の両成分が必要で ある. soft segment は BR，IR，ポリエーテルなどを用い る、 hard segmentには，(1)凍結相によるもの，(2)水素 結合によるもの，(3)結晶相によるもの，(4)イオン架橋に よるものがある． hard segmentの分子間凝集力により 物理的架橋を形成する. segment の種類，拘束様式，分
子量, 分子配列などにより多種類の TPE が表 1 及び図

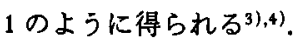

現在市販されている TPE む数多く(表 2 )(1)スチレン 系(TPS)，(2)オレフィン系(TPO)，(3)エステル系 (TPEE)，(4)ウレタン系(TPU)，(5)その他 TPEに大別 される. TPS, TPO, TPU 及びTPEE は 4 大 TPE と呼 ばれる，その他の TPEには，1,2 ポリブタジェン(以下

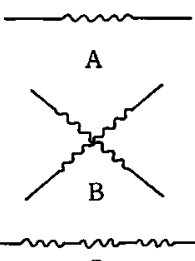

C
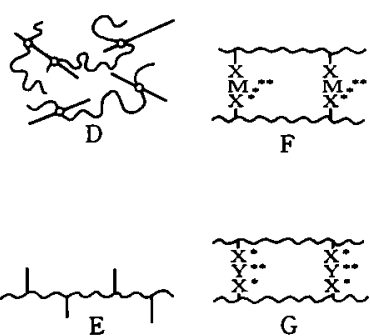

図 1 モデル構造による熱可塑性エラストマーの分類3

A : トリブロック (triblock)

B : ラジアルブロック (radial block)

C : マルチブロック (multi block)

$\mathrm{D} ：$ 樹脂-ゴムブレンド

$\mathrm{E}:$ グラフトポリマー

F：金属塩クラスターによる拘束

$\mathrm{G}$ : 第 4 級アンモ二ウム塩による拘束

一硬質セグメント 〜軟質セグメント

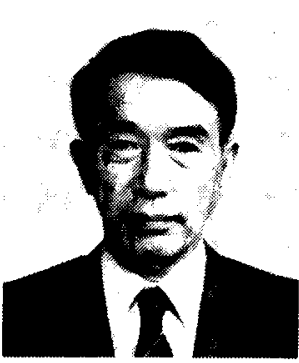

*日本合成ゴム侏（テ104 東京都中央区筑地 2-11-24) 合成ゴム本部技術部参事. I 博. 昭和 30 年横捠国立大学工 学部卒業、ブリヂストンタイ 十㧣（当時）を経て38年日本 合成ゴム琍に入社，現在に至 る

〈趣味〉ヨガの研究，情報の 研究，音楽，水泳，っりなど 
表 1 エラストマーの分類引

$$
\begin{aligned}
& \text { [タイプ〕【拘束様式] } \\
& \text { エラストマー [ }
\end{aligned}
$$

表 2 主要 TPEの分類とメーカー6)

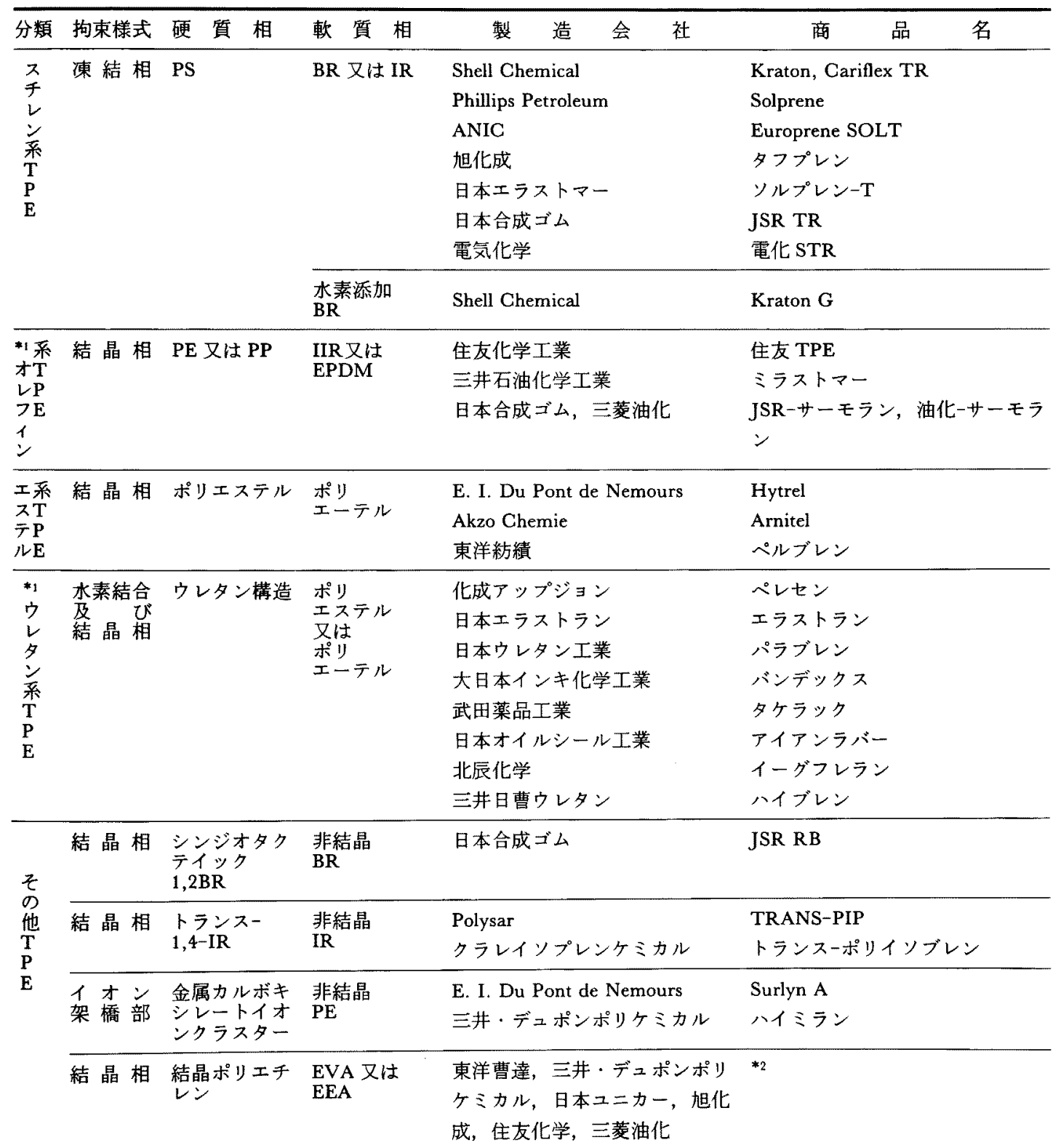


概

\begin{tabular}{|c|c|c|c|c|}
\hline $\begin{array}{l}\text { 水素結合 } \\
\text { 芯 } \\
\text { 結晶相 }\end{array}$ & $\begin{array}{l}\text { 結晶 PVCほ } \\
\text { 力 }\end{array}$ & $\begin{array}{l}\text { 非結晶 } \\
\text { PVC }\end{array}$ & $\begin{array}{l}\text { 住友ベークライト } \\
\text { 三菱モンサント化成 } \\
\text { 電笑化学工業 } \\
\text { 信越ポリマー } \\
\text { チッソ } \\
\text { 東亚合成化学 }\end{array}$ & $\begin{array}{l}\text { スミフレックス } \\
\text { サンプレーン } \\
\text { ビニコン } \mathrm{R} \\
\mathrm{EZ}-800 \\
\text { エラスリット } \\
\text { アロンエラスト }\end{array}$ \\
\hline 結晶相 & $\begin{array}{l}\text { 結晶ポリエチ } \\
\text { レン }\end{array}$ & $\begin{array}{l}\text { 塩素化ポリエ } \\
\text { 千レン }\end{array}$ & $\begin{array}{l}\text { 昭和油化 } \\
\text { 大阪曹達 } \\
\text { Dow Chemical }\end{array}$ & $\begin{array}{l}\text { エラスレン } \\
\text { ダインラック } \\
\text { Dow-CPF }\end{array}$ \\
\hline $\begin{array}{l}\text { 我素結合 } \\
\text { 莨 } \\
\text { 結晶相 }\end{array}$ & ポリアミド & $\begin{array}{l}\text { ポリ } \\
\text { エーテル } \\
\text { 又は } \\
\text { ポリ } \\
\text { エステル }\end{array}$ & $\begin{array}{l}\text { Hüls } \\
\text { ATO Chimie } \\
\text { ダイセル化学 } \\
\text { 大日本インキ化学工業 }\end{array}$ & $\begin{array}{l}\text { Vestamid } \\
\text { PEBA } \\
\text { ダイアミド-PAE } \\
\text { グリラックスA }\end{array}$ \\
\hline 結晶相 & フッ素樹脂 & フッ素ゴム & ダイキン工業 & ダイエルサーモプラスチック \\
\hline
\end{tabular}

*1 オレフィン系及びウレタン系TPEでは外国メーカーを除外した。

*2 EVAの商品名はTPEとの関連で不明な点があるので割愛した。

RB)，PVC系，ポリアミド系など独自なもの及び最近 開発された TPE が含まれる。

TPE の洒格から(1)一般用 TPE (約 500 円 $/ \mathrm{kg}$ 以下， TPS, TPO, RB), (2)エンジニアリング TPE(1,000円 $/ \mathrm{kg}$ 以上, TPEE, TPU,フッ素系など)，(3)中間の TPE(ア イオノマー，塩素化ポリエチレンなど)にも分類できる.

\subsection{TPE の特}

TPE は奏用的に次のような特幑を有する $33,61,11)$.

1）熱可塑プラスチックの成形機で加工でき加硫工程 を必要としない，ゴム工業などの省エネルギー，工程合 理化に貢献できる。

2）加硫ゴムからプラスチックまで広範囲の性質をも つ製品を tailor made につくれるので，市場の多様化に 詨忘できる。

表 3 ゴム状物筫の加工程における 所要エネルギー19)

\begin{tabular}{|c|c|}
\hline$フ^{\circ}$ 口 & 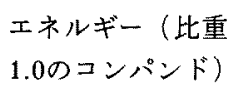 \\
\hline バンバリー(一段ベールより) & $3-4 \mathrm{GJ} / \mathrm{m}^{3}$ \\
\hline ロールミル混合(ベールより) & $15-35$ \\
\hline プレミックスコンパンドの加 & 2 \\
\hline 加熱押 出 $\mathrm{L}$ & $1-2$ \\
\hline 冷 押 出 し & $2-3$ \\
\hline インジェクションモールド & 1 以下 \\
\hline
\end{tabular}

3）得られる製品は化学架橋がないためスクラップの 回収・再利用が容易である、

4）プラスチックなどに新しい弾性機能を付与する

例えば，ゴムの加工工程における所要エネルギーのコ ンピュータ解析の結果では(表 3, 表 4)インジェクショ ン加工の消費エネルギーが極めて低い，また，同じイン ジェクションでも等东準の品質にある成形品を得るため 総エネルギーはCRより TPEEのほうが低い19)。高圧 ホースの例では(図 2)メータ当たりの所要エネルギー が，TPEEは加硫ゴムのわずか38\%にすぎない10).TPE を用いた新しい材料，新しい市散については後述する.

一方，TPEには次のような欠点もある。

1）耐熱性にそしく大部分のものは $100^{\circ} \mathrm{C}$ 以下での使 用に制限され，特殊なものでも150年以下である。

表 4 インジェクションにおける TPE と 加硫ゴムの比較

\begin{tabular}{|c|c|c|}
\hline & TPEE & 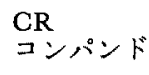 \\
\hline 製品の重*1 & $0.666 \mathrm{~kg}$ & $0.114 \mathrm{~kg}$ \\
\hline コンバンドのエネルギー & $14.8 \mathrm{MJ}$ & $15.7 \mathrm{MJ}$ \\
\hline $\begin{array}{c}\text { 加工に要するエネルギー } \\
\left(\begin{array}{l}\text { (混合, 成型, 冷 } \\
\text { 却, 加硫含む含 }\end{array}\right)\end{array}$ & $0.07 \mathrm{MJ}$ & $0.3 \mathrm{MJ}$ \\
\hline スクラップエネルギー*2 & $0.2 \mathrm{MJ}$ & $1.0 \mathrm{MJ}$ \\
\hline 計 & $15.1 \mathrm{MJ}$ & $17.0 \mathrm{MJ}$ \\
\hline
\end{tabular}

*1 製品のパホーマンスが同一になるよう設計。

*2 TPEEの值が低いのは粉粋, 再使用, バリの有利 性による。 

小松 公栄

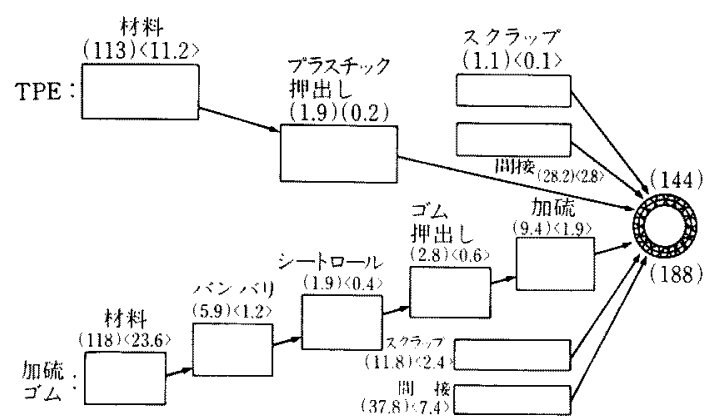

図 2 高圧ホース生産時の所有エネルギー10)

注）（）内の数字：製品 $1 \mathrm{~kg}$ 当たりのエネルギー $(\mathrm{MJ} / \mathrm{kg})$

〈〉内の数字: 製品 $1 \mathrm{~m}$ 当たりのエネルギー $(\mathrm{MJ} / \mathrm{m})$

2）高温で使用できるTPEでも高硬度を維持するこ とはむずかしい。

3）機戌的性質や耐環境性など改善すべき点が多い. 表 5 に主要な TPEの相当比較を, 図 3 に応力ーひずみ 举動を示した。 また，図 $4 \sim 6 に \mathrm{TPE} の$ 適用温度範囲， 耐油性，硬度範囲を示した ${ }^{10)}$ 。おのおののTPEはそれ ぞれ特徽があり，ここではとうてい議論できないのでく わしくは各論を参照されたい15).

なお，TPEはプラスチック加工機械で成形し，バン パリミキサ，コンテナスミキサ，ヘンシェルミキサの使

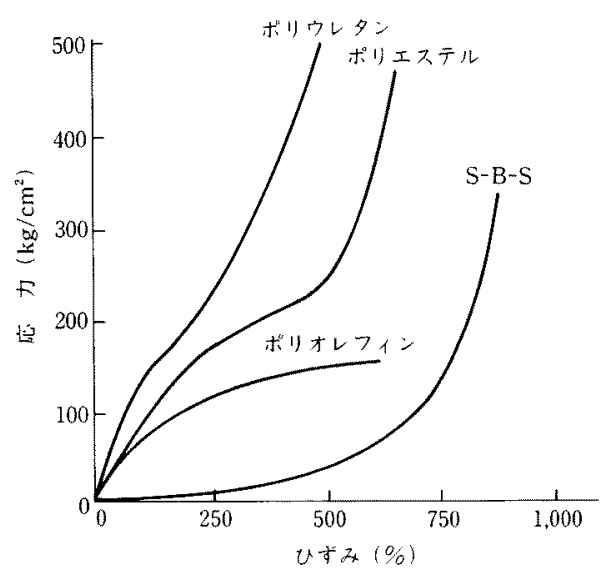

図 34 大 TPE の応力ーひずみ挙動 334

用，インジェクション成形，押出成形，トランスファ成 形など可能である、まだ，新しい材料のためまとまった 情報が少ないため791,11)，本誌各論やプラスチック加工 成書を参照されたい(5),80)。

\section{3. 市場・技術開発の動向}

\section{1 市埸動向}

世界及び日本における新ゴム消費量を表 6 に示す. TPEの世界に扣ける需要動向を図 7 に、アメリカの動 向を表 7 に示す. 1980年の TPE は世界で20万トン強,

表 5 代表的 TPE の性能比較 ${ }^{78}$.21

\begin{tabular}{|c|c|c|c|c|c|c|c|c|}
\hline 性能, 用途 & 分 & 類 & TPS & TPO & TPU & TPEE & $\begin{array}{l}1,2 \text { ポリプ } \\
\text { タジンン* }\end{array}$ & PVC系 \\
\hline \multicolumn{3}{|c|}{ 相対的材料価格 } & $0.45 \sim 0.70$ & $0.35 \sim 0.62$ & 1.0 & $1.3 \sim 1.4$ & $0.3 \sim 0.5$ & $0.3 \sim 0.6$ \\
\hline 比 & & 重 & $0.95 \sim 1.10$ & 0.89 & 1. $13 \sim 1.26$ & $1.12 \sim 1.19$ & $0.89 \sim 0.92$ & $1.22 \sim 1.32$ \\
\hline 硬 ショア & $\mathrm{A} / \mathrm{I}$ & D) & $30 \mathrm{~A} \sim 70 \mathrm{~A}$ & $75 \mathrm{~A} \sim 65 \mathrm{D}$ & $80 \mathrm{~A} \sim 60 \mathrm{D}$ & $90 \mathrm{~A} \sim 70 \mathrm{D}$ & $19 D \sim 55 D$ & $40 \mathrm{~A} \sim 70 \mathrm{~A}$ \\
\hline 柔 軟 & & 性 & (O) & $\triangle \sim O$ & $x \sim \triangle$ & $\triangle$ & (O) & (O) \\
\hline 機 械 的 & 強 & 度 & 0 & $\triangle$ & (2) & (O) & $\triangle$ & 0 \\
\hline \multicolumn{3}{|c|}{ 圧樎永久ひずみ } & $\Delta \sim 0$ & $x \sim 0$ & (9) & 0 & $\bigcirc$ & $\triangle$ \\
\hline 低＼cjkstart温 & 特 & 性 & 0 & 0 & $x$ & 0 & 0 & $\triangle$ \\
\hline 高＼cjkstart温 & 特 & 性 & $x \sim 0$ & 0 & $\triangle$ & (2) & $\triangle$ & $x$ \\
\hline 耐候 & & 性 & $x \sim 0$ & 0 & 0 & (2) & 0 & $\bigcirc$ \\
\hline 耐 & & 性 & $x$ & $x$ & 0 & (C) & 0 & $\bigcirc$ \\
\hline 酎 熱 & 水 & 性 & 0 & 0 & $x$ & $x$ & 0 & 0 \\
\hline 加 I & & 性 & & & & & & \\
\hline 射 出 & 成 & 形 & (Q) & $\mathrm{O}$ & $\triangle$ & 0 & 0 & $\triangle$ \\
\hline 押 出 & 成 & 形 & $\triangle \sim 0$ & $\triangle \sim 0$ & $\triangle$ & $\triangle$ & 0 & (9) \\
\hline
\end{tabular}

\section{*1 筆者加筆}




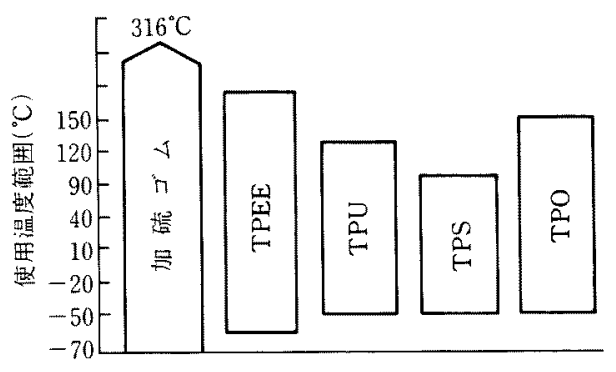

図 44 大 TPE の温度範囲 ${ }^{103}$

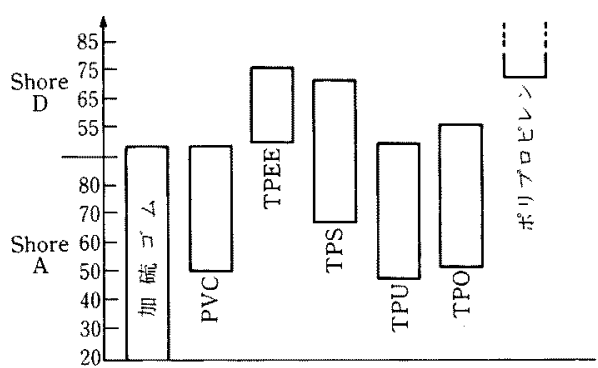

図 54 大 TPE の硬度範囲 ${ }^{10}$

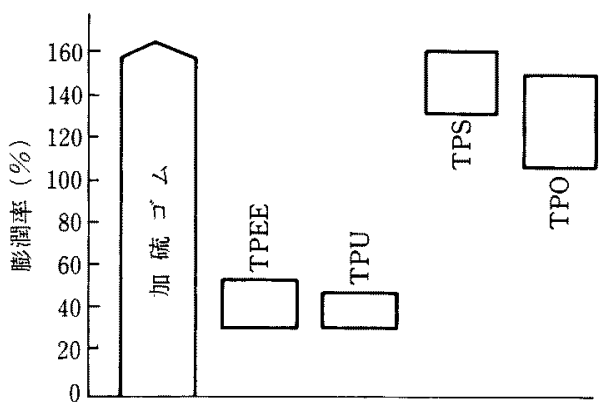

図 64 大 TPE の耐油性 ${ }^{10\}}$

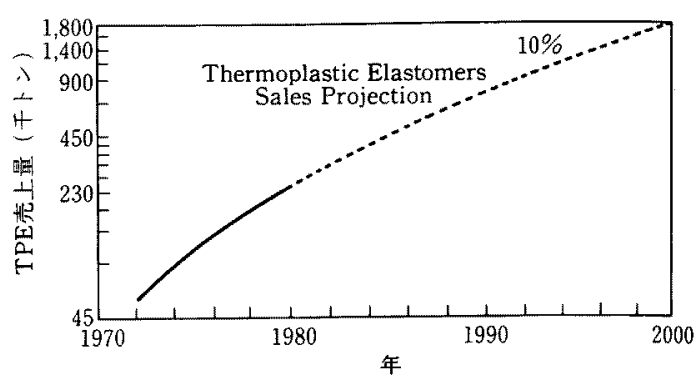

図 7 世界の TPE の売上推移101

——:害績, - - - : 予測(成長率10\%)

アメリカで15万トン強, 日本で4万トン強の需要とみら れる61,12),14)。年間成長率は，これまでの実績でもちろ ん今後も $10 \%$ 以上見込まれており，新ゴムの成長率 $3 \sim$ $4 \%$ に比較してTPEの成長率は高く，1985年には世界 で45万トンに達しようとしている.

1965 年 Shell 社がスチレン系TPEのブロックコポリ マーKratonを世界ではじめて上市して以来，履物，接 着剂, 自動車用品, ホース, 電線などの工業用部品を中 心に伸長しており，市場は多蚑にわたっている(表 8). 加硫ゴムとプラスチックスの境界領域を中心に TPEは 発展しつつあり，模式的に図8のように表される゙1. 1980年アメリカにおける4大TPEの需要のうち, 加硫 ゴム分野へ $60 \%$ ，熱可塑プラスチックへ3\%，ほかの TPE への置きかえ $15 \%$ ，金属代替へ $2 \%$ といわれる24). (表 9). 最近の㑯向として，プラスチック改良分野，電 線，ケーブル，接着剤・粘着剤分野，高付加洒值分野の 伸び率が特に高い傾向がみとめられるものの(表10)，す

表 6 世界及び日本の新ゴム消費量 ${ }^{181}$

(単位: $t$ )

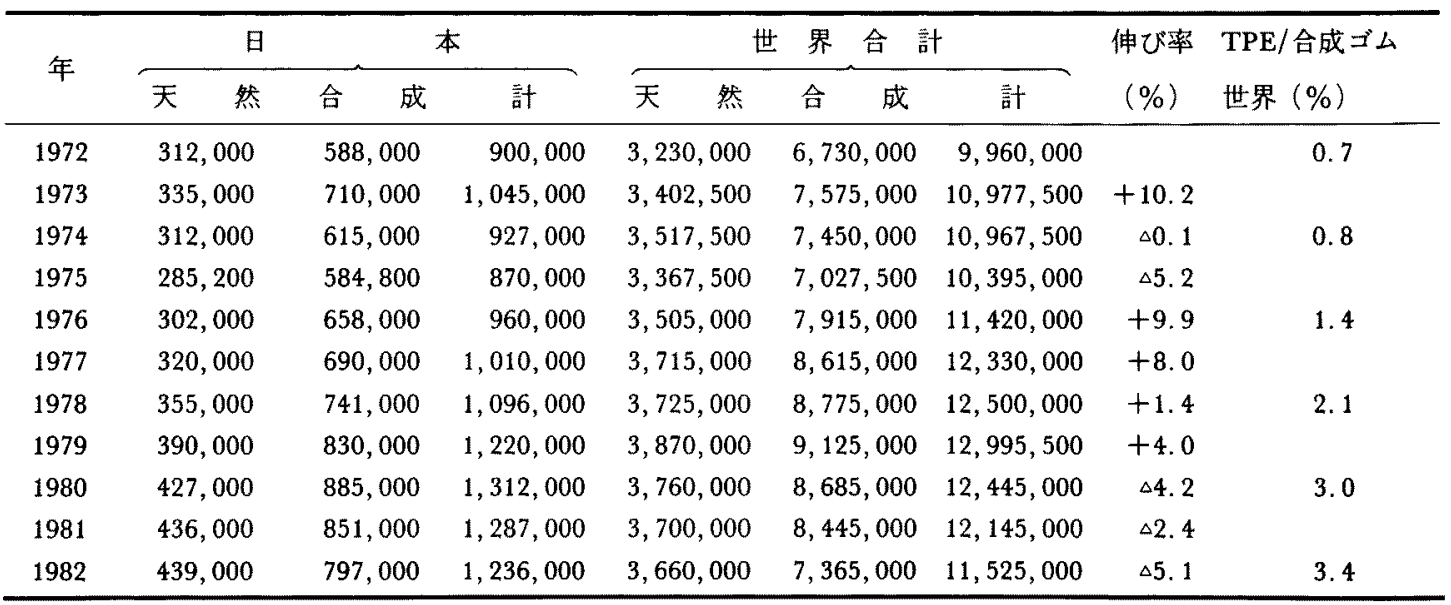


表7 アメリカにおける4大TPEの需要推移融

\begin{tabular}{|c|c|c|c|c|c|c|c|c|c|c|c|}
\hline & & & $1973^{\text {a) }}$ & $1974^{a)}$ & $1976^{\mathrm{b})}$ & $1977^{\mathrm{bl}}$ & $1978^{c)}$ & $1979^{c)}$ & $1980^{c)}$ & $1981^{d)}$ & $\begin{array}{l}1986^{\mathbf{a})} \\
\underset{龴}{J}\end{array}$ \\
\hline $\mathbf{T}$ & $\mathbf{P}$ & $\mathrm{S}$ & 16.5 & 20.0 & 67.5 & 65.3 & 73 & 85 & 93 & 107 & 172 \\
\hline $\mathrm{T}$ & $\mathbf{P}$ & $\mathrm{O}$ & 0.9 & 1.4 & 9.0 & 14.4 & 16 & 19 & 22 & 18 & 36 \\
\hline $\mathrm{T}$ & P E & $\mathrm{E}$ & 1.3 & 1.6 & 2. 3 & 3.2 & 5 & 6 & 7 & 4.5 & 9 \\
\hline $\mathrm{T}$ & $\mathbf{p}$ & $\mathrm{U}$ & 12.7 & 16.4 & 13.5 & 19.8 & 23 & 27 & 30 & 20 & 27 \\
\hline
\end{tabular}

a) Rubber World, p. 43 (1975/2)

b) Thermoplastic Elastomers-II, R. M Kossoff \& Ass. (1978/12)

c) IISRP Ann. Mt' g, 21th (1980/4)

d) ACS Rubber Div. Mt' g. 120, No. 31 (1981)

表 8 主要 TPEのマーケットク

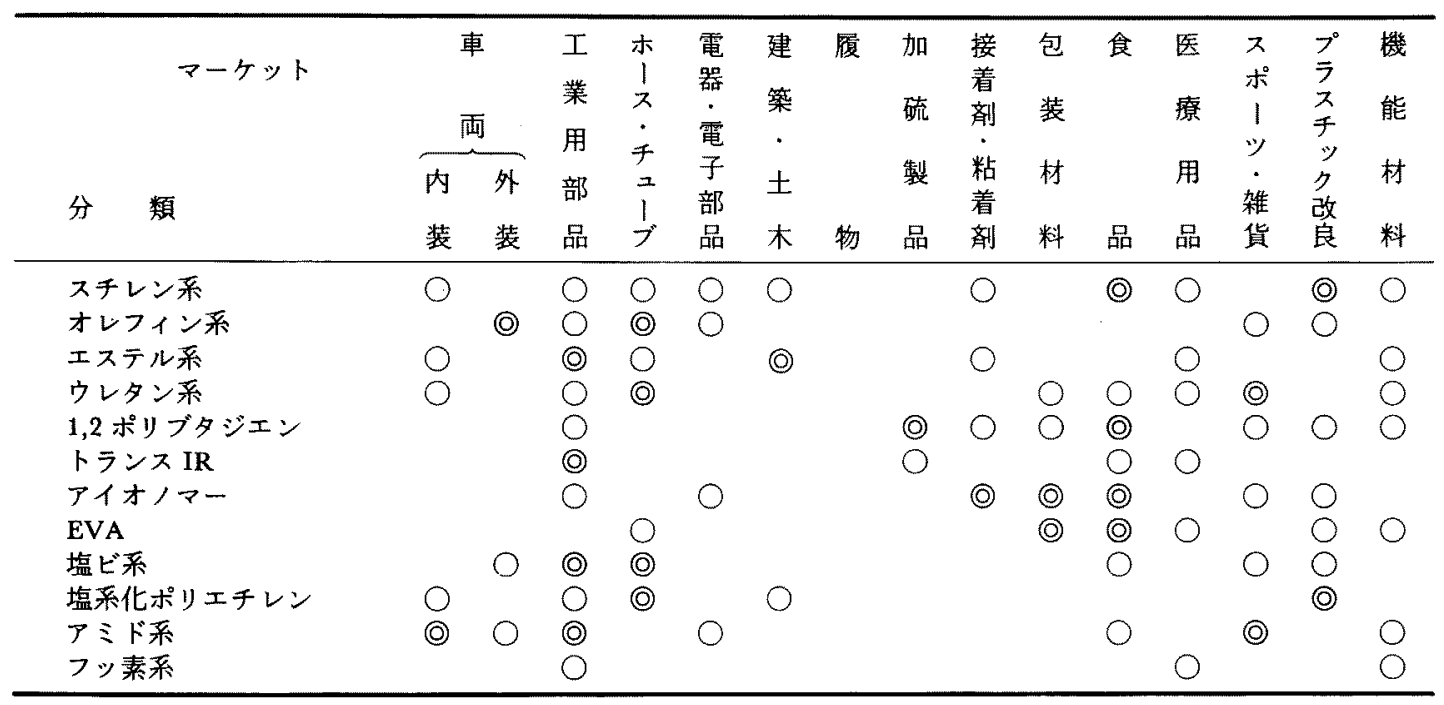

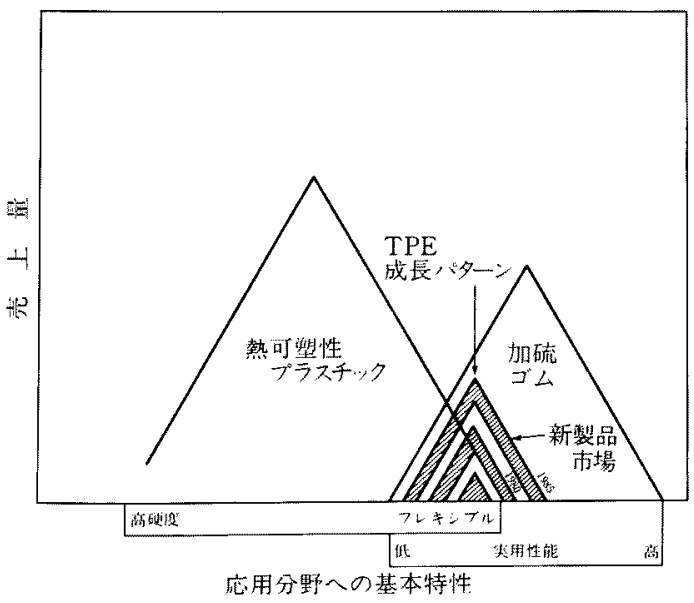

図 8 プラスチックと加硫ゴム及びTPEの売上量と基 本特性を示す模式図 ${ }^{(1)}$
表 9 アメリカにおけるTPEの進出分野24)

\begin{tabular}{|c|c|c|c|c|c|}
\hline & $\begin{array}{l}\text { 加硫 } \\
\exists ゙ ム\end{array}$ & $\begin{array}{l}\text { プラスチ } \\
\text { ックス }\end{array}$ & $\begin{array}{l}\text { 他の } \\
\text { TPE }\end{array}$ & $\begin{array}{l}\text { 金風 } \\
\text { そのほか力 }\end{array}$ & 計 \\
\hline $\mathrm{T} \quad \mathrm{P} \quad \mathrm{S}$ & $62 \%$ & $31 \%$ & $5 \%$ & $2 \%$ & $100 \%$ \\
\hline $\mathrm{T} \quad \mathrm{P} O$ & 65 & 13 & 22 & - & 100 \\
\hline $\mathrm{T} \quad \mathbf{P} \quad \mathbf{U}$ & 60 & 7 & 23 & 10 & 100 \\
\hline T P E E & 57 & 14 & 29 & - & 100 \\
\hline 計 & 60 & 23 & 15 & 2 & \\
\hline
\end{tabular}

ベての分野にわたって伸びている。

\section{2 技術動向}

最近の技術開発の動向は，ほぼ4つの方向に集的され る.すなわち，(1市場の要請に合うような cost-performance の改良及び用途開発，(2)新しいグレードの開 
表104大 TPEの分野別推移 ${ }^{78)}$

(単位\%)

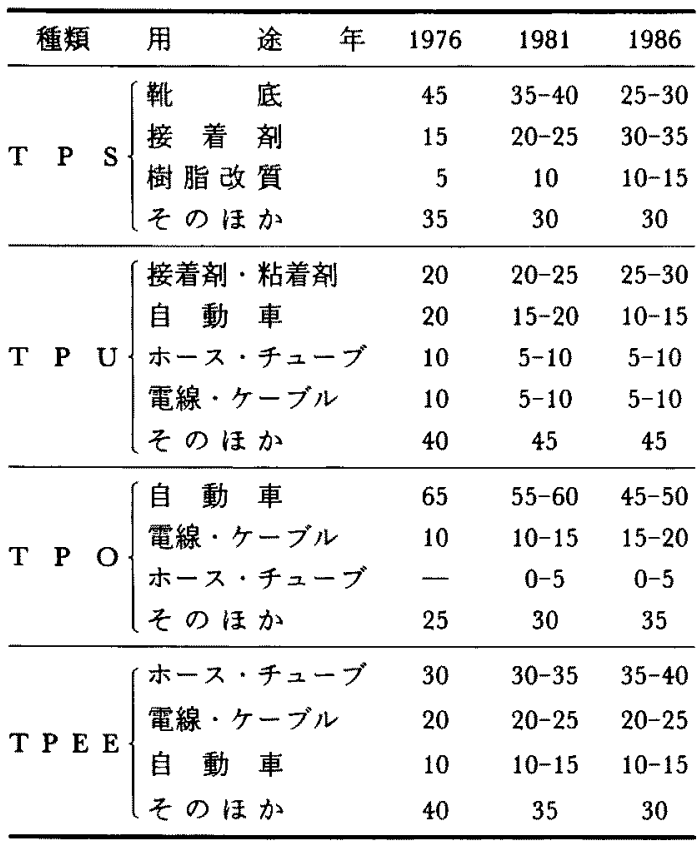

発，(3)新しいタイプの TPEの上市，(4)高付加値価值 · 高機能化型の新 TPEの研究が盛んである．新しい要素 技術のいくつかについて次にしるす。

3.1.1 プラスチックブレンド プラスチックの耐衝 摯性や柔軟性などの改良に弾性を付与し改良するが， TPE はプラスチックと相溶性のよい硬質相を所有し， グリーン強度が強いため改質剤として有効であり，この 分野の需要が急伸している，例えば，耐衝撃性ポリスチ レン(HIPS)はBRにスチレンモ/マーをグラフト重合 してっくるが，TPS をべースにすると耐衙撃性及び透 明性が大幅に增大寸る、一般用ポリスチレン(PST) と TPS の単純ブレンドにより，従来の HIPS に匹敵する ものが得られる27),299.

高密度ポリエチレンフィルムやアスファルトの強度向 上に TPS が成功している27). シンディオタック 1,2-ポ リブタジエン $(\mathrm{RB})$ と EVA ブレンド物が履物底に広く 使われている2),30).

自動車のフルパンパーへの TPOの使用はヨーロッパ が早く，1978年にすでに 2 万トン使用されているが31)， 最近日本で PP-EPDM ブレンドTPO が急伸してい $3^{32)}$

エンジニアリングプラスチックス(Enpla)にじん性を 付与して強化することに TPEが使用されている．例え
ば，飽和型 TPS Kraton $G^{33)}$, TPEE-ナイロン $6^{34) ， ア イ ~}$

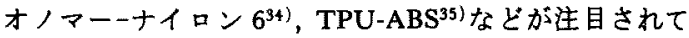
いる.

3.1.2 非均ーブレンド Inter-penetrating Polymer Network(IPN)は二つ以上のポリマーが相互にからみ合 い架橋したもので，相溶性の少ないポリマーをブレンド するための有効な技術の一つである ${ }^{36}$ ．IPN の歴史は 古く，すでに1960年に発表があったが，1970年後半まで はさしたる進展はなかった。しかし，最近の ABC(Alloy, Blend, Composite)時代を反映して研究及び 実用化が進んでいる。

IPN をつくる方法はグラフト重合など種々の方法が あり，TPEを用いるのも有効な手段である ${ }^{37}$. TPE と してはじめての IPN 商品 Kraton IPN" が発表され ${ }^{35), 88) ~}$ 注目されている。 TPUをべースとした semi IPNシリコ ン樹脂が開発されている(1),39)。ほかに Kratont"-ポリ ブチレンテレフタレート, 部分架橋 EPDM-PP など IPN に関する研究も増加の方向にある17),18).

3.1.3 加硫ゴム分野への適用 TPE は本来非加硫で 使用されるが，一般ゴムとブレンドしてTPEそのもの を加硫して使用する新しい市場が成功している，その代 表的なものは RB で2，40)，高硬度加硫ゴム製造時の流動 性改良や加硫発泡スポンジに使用されている，また，廃 タイヤゴム粉末にTPS あるいはRBを混合して加工性, 物性を改良する方法が開発されている(11)。この分野は RB など加硫できる一部の TPE にしか適用できないか， ゴム工業に㧍けるインジェクション加硫なと゚今後効率化 がらみで発展が期待される。

3.1.4 高性能・高機能分野への展開 各 TPE で用途 開発，グレード開発を行われている，高性能化への挑戦 例として，例えば TPU 及び TPEE での射出成形タイヤ の開発があり，実用に耐える段階まできているといわれ る ${ }^{42)}$ 。また， $212{ }^{\circ} \mathrm{C} の$ 融点を有するポリエーテルアミ ド日)，長持間 $150^{\circ} \mathrm{C}$ 耐熱を維持できるポリエステルア ミド8)が開発されている.

TPS 耐熱性向上, TPU の耐溶剤性改良，TPEE にお ける耐光・耐熱性向上などの高性能化への努力が行われ ている20).

一方電子材料分野へは，導電性 TPA として TPO ${ }^{92)}$, TPU 及びポリアミド+2)，超 LSI 積層板へのRB の展 開(6)，微細パターン用導電コネクターへの応用(4)，電子 材料グレードTPSなどが举げられる，また，医㞠用材 料として人工血液ポンプ及び人工血管用 TPU ${ }^{45}$ ，抗血 栓フッ素 TPE ${ }^{46)}$ ，カチオン交換瞙としての SIS プロッ 
クコポリマー47)などの研究があり今後の実用化が期待さ れている.

\section{4 、各種 TPE の動向}

詳練については，各論で記されるのでトピックスを中 心に簡単に述べる。

\subsection{TPS}

スチレンーブタジエン(又はイソプレン)ースチレンブロ ックコポリマー(SBS 又は SIS)及びSBSを氷素添加し た飽和型の SEBS に大別される。

SBS はTPEの原点というべきポリマーであり, Shell 社が世界ではじめて1965年に linear blockを, Phillips 社 が1973年に radial blockを上市して以来，履物底を中心 に現在20万トンが生産されている最大の TPEである。 日本では最近電気化学及じ日本合成ゴムがこの分野に参 加しており，アメリカでも Firestone が1982年に上市， ARCO む研究中といわれる。一方, Phillips 社がアメリ カのプラントを閉鎖しており，SBS を取りまく環境も 変動している。

SIS は感圧接着剤を中心に, SEBS は Enpla modifier を中心に急成長しており，IPN type を含めて高付加価 值分野を中心とした展開が期待される。

\subsection{TPO}

1972年 Uniroyal の部分架橋型 TPO が最初であるが、 量的には PP と EP(D)M 単純ブレンド TPO が主体であ る。日本で 3 社が生産し9,000トンといわれるが，自動 車バンパ用などポリプロメーカーやレジン加工メーカー が自社生産しており実態は不明である、新しいTPO と しては Monsanto 社の “Santoprene” と Ferro Co.の自 動車向け“Ferroflex”が注目される，前者仙動的加硫技 術によりポリオレフィン中に EPDM の完全加硫粒子を 分散させたもので，低圧縮永久ひずみ，CRなみの耐油 性を有する(4),24)、25)，後者の詳細は不明であるが耐熱性 及び強曲げ強度が特徵である25). いずれもゴムの加硫技 術が応用されている意味で注目される。

なお，TPO でゴム分の少ないものを EMT(elastomer modified thermoplastics)として区別することがある.

\subsection{TPEE}

需要は現在アメリカで5,000〜7,000, ヨーロッパで 2,000 ，日本で1,200トン/Yといわれ，年間成長率も15 \%以上で最む成長が期待されるTPEである，日本で東 洋プロダクトの3,500トン/Yプラントのスタート，東洋 紡の増設 $(1,000 \rightarrow 3,000$ トン)が発表されている、デェポ ンのヨーロッパでの8,000トン/Yプラントのスタート
(1984年)，アメリカにおける GAF 社の上市及び GY 社 のパイロット発表があり 24),48)，TPEEの急成長市場を ねらったメーカーの競合も激化しよう。

\subsection{TPU}

TPUは現在アメリカで20,000トン，コーロッパで 16,000 トン, 日本で 4,000 トン/Yの需要とみられ $3^{18), 24)}$.1958年(Goodrich Gulf 社が上市した最も古い TPEであるが，ウレタン RIM(Reaction Injection Molding)やR-RIM(Reinforced RIM)に押され，ほかの TPEほど成長していない618)。しかし，RIMにも成形時 間などの問題があり，TPUの見直し気運が高まり日本 でも TPU 郎話会が発足している6),49\}.

\section{$4.51,2$-ポリブタジェン(RB)}

日本合成ゴム(JSR)が1974年から10,000トン/Yの生 産を続けており，フィルム，履物，接着剂，電子材料な どの市場が広がっている30).40\}，特にすでに述べた加硫 分野への適用は，他の TPEに見られないRBの特性て 今後の展開が期待される。 RB の加硫性，ゴムへの分散 性，低融点を生かしたゴム薬品やカーボンをRBで包装 して直接バンバリーに投入できる溶融としての応用が 進んでいる.

\section{6 エチレン系(EUA, EEA, アイオノマー)}

エチレンー酢ビコポリマー(EVA)，エチレンーアクリ ル酸エチルコポリマー(EEA)，エチレンーアクリル酸の イオン架橋ポリマー(アイオノマー)は，いずれる歴史が 古くプラスチックスとして発展してきた，軟質相のゴム 弾性に問題があり，一般的にはTPEとしては取扱われ ていない.しかしながら TPEとして分類している例も

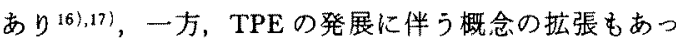
て，今後TPEとして取り扱うべき組成のポリマーが存 在し，用途もTPEと類似しているので本誌にて採り挙 げた.

\section{7 トランスポリイソプレン}

合成トランス IR・クラレは世界で唯一生産を行って おり，別に天然のガッタパーチャがある、いずれたラ ンスー1,4-構造99\%と高純度であり，TPEとして注目さ れるようになったのは最近である，加硫分野人の適用が

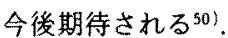

\section{8 塩化ビニル系 TPE}

1967年三菱モンサント(怢がはじめて上市しているが， TPE として本格的検討が行われるようになったのは， 1978年住友ベークライト(侏が低圧縮ひずみの“スミフレ ックス”を発表して以来である61,52)，世界的にも日本以 外での上市はなく，一方，日本の主要メーカーはほとん 
ど手がけている.ホース用を中心に市場開発が行われて いるが、まだ新しい材料であり今後の展開が注目され $3^{16) .75)}$

\section{9 塩素化ポリエチレン(CPE)}

CPE 及びクロロスルホン化ポリエチレン(CSM)の歴 史は古くCPS は1960年代, CSM は1952年に世界で上市 されている。CPEは1969年からも日本国産化の動きが 出ている. CPEがTPEとして注目されるようになった のは,この 2〜3年のことで，よりゴムに近いCSM は まだ TPEとして取报ったものはない，

CPS 及びCSM とも樹脂ブレンドなどTPEとしての 用途も多く，耐焰性，耐候性，耐オジン性などの特性を 備えているので，ポリマーのグレード開発と相まって今 後開発が加速すると予想される。

\subsection{0 ポリアミド系 TPE(TPAE)}

上市されているTPEで最も新しく開発されたもので， 1979年 Hüls 社が hard segment としてナイロン, soft segment としてポリエーテル(又はポリエステル)を用いた ブロックコポリマーを発表したのが最初である43),51).

DuPont 社のポリエステルアミドの基本特許が消減した こともあって，世界的に開発が加速されている，日本て はダイセル化学(侏が Hülsの技術でナイロン12系で上市 したのがはじめで，その後，大日本インキ化学工業侏珄及 び三菱化成侏が Emser Werke 社の技術上市又は開発中 である. 海外でも Hülsのほかに Akzo 社, ApJohn 社, Rilsan 社が上市及び㛟討中である。TPAEは新しい TPEA であるが，ナイロンの有するタフネスを軸に TPEE TPUと競合していこう.

\subsection{1 フッ素系 TPE}

1982年秋にダイキン工業(侏がフッ素ゴム成分とフッ素 樹脂成分を結合したTPE を発表した”7.フッ素系では 世界で唯一のものであり，また上市されているTPEで は最も新しいものとして注目されている ${ }^{58), 76)}$. 現在射 出成形温度 $230^{\circ} \mathrm{C}$ と $160^{\circ} \mathrm{C}$ の 2 グレードが市販されている が，15,000円 $/ \mathrm{kg}$ と高価格である.このようなエンジニ アリング TPEの今後の動问は極めて注目される.

\subsection{2 天然ゴム TPE(TRNR)}

NR をPP PE とブレンドしたTPNR が開発されて 商業規模で生産中である ${ }^{53), 54)}$. 耐熱性や強度に特徵が あり，耐候性も奏用上問題がないといわれる。また，塗 装性がよくコストも TPOより10\%安いといわれ自動車 部品を主として展開中である，MMAなどをNRにグ ラフトしたTPE 開発されているが，コスト的に問題 がある．最近変性ポリスチレンをNRとミキサーで混
ぜるだけでグラフトする万法す開発され注目される55.

\subsection{3 研究開発ステージの TPE}

Uniroyal 社は EPDM をスルホン化したアイオノマー 型 “Eonic Elastomer”発表している゙6). Exxon 社のラ イセンスを受けて，現在市場開発を行っているが，まだ 上市に至っていない8)。ホットメルト接着風用に Du Pont 社からアクリル系三元重合体 “Vamac Ionomer" が発表されている57).

クロロスルホン化ポリエチレンと水酸化ナトリウムを 溶かしたポリエチレングリコールと反応させた親水性ス ルホネート・アイオノマータイプの TPEが，工業技術

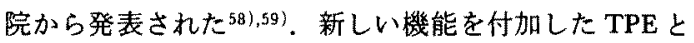
しての発展が期待される。また，TPSに無ホマレイン 酸を付加させたアイオノマー60),73)，新しいタイプのア イオノマー62)，ウレタンアイオノマー65)など極性モ， マーによるイオン架橋法を導入した TPEの発表が多い， 拘束相に新しいポリマーを使用する研究として，ポリ ピパロラクトブロックコポリマー63),64)，ニトリルグラ フト化 $\mathrm{EPDM}^{62)}$ ，スチレンーニトリルグラフト化 TPEE ${ }^{66)}$ スチレンの代りに $\alpha$-メチルスチレンを用いた TPS $^{671}$ などの研究が行われているが，一長一短があり 上市に至っていない.

ポリスチレンーポリジメチルシロキサン68), ポリスル ホンーポリジメチルシロキサンブロックコポリマー69),

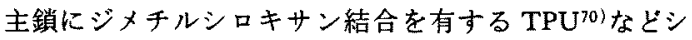
リコン系TPE も研究されている，また，1,4-シクロ人 キサンジオールを用いた $\mathrm{TPEE}^{\mathrm{11})}$, 交互ポリエステルア ミド72)，など新しいTPEの咞究もある、ブレンドや構 造, 分析, 物性の研究も盛んであるが割愛する.

TPEの合成法は現在，(1)アルキルリチウムによるア ニオンリビン重合，(2)重樎合，(3)チーグラー触媒重合 (TPO)が主体で, (4)ラジカル重合, (5)グラフト重合な ども一部手法として使用されている．最近，DuPont 社 がシリルカチオンによってアクリルモノマーが完全なり ビング重合することを発表している74)（ほかにも高分子 合成法の研究は盛んであり，複合化の研究と相まって今 後とも新しいTPE が出現する可能性は高い。

\section{5.おわりに}

TPE はゴム工業などの省資源・省エネルギ一材料と して安定な成長をとげている，加えてゴムとプラスチッ クの両特性を備えた新材料として新しい用途が開けつつ あり，今後とも成長が期待されている，それだけに新規 参入メーカーも多く，液状ゴムや RIMなどの他の材 
料，又はTPEどうしでの競合が激化していることも自 明である。

各 TPE の発展の鍵は品質(Performance)と価格のバラ ンスであろう。その意味で各 TPEメーカーの一蟹の努 力が不可欠であり，同時にユーザーサイドからの指導 . 協力を得た商品開発が重要である．特にプラスチック加， 工と異なる複雑なゴム加工技術を応用したTPE をべー スとした商品はまだ少なく, 今後第 2 世代の TPE 商品 として期待される.

\section{引用 文 献}

1) 大柳 康：高分子，29，739(1980)

2) Kuramoto, K., Komatsu, K.: IISRP, 20th Meeting, Vancouver (1979)

3）山下晋三： "Plastic Age Encyclopedia 進歩編”, p. 300, プラスチック・エージ社(1978)

4) 小松公栄 : ibid, 1981, p. 2617 (1980)

5）古川淳二監修，高分子技術研究会：“高性能エラス トマーの開発” 大成社(1979)

6）小松公栄：プラスチックエージ，28[3]，67 (1982)

7）小松公栄：ibid, 29，〔10]，79（1983)

8) Walker, B. M.: J Elastomer of Plastics, 14, 139 (July, 1982)

9) Auchter, J. F.: ACS Rubber Division, Cleveland (Oct. 14, 1981).

10) Hargreaves, Chester A: IISRP, 23rd Meeting, New Orleans (1982).

11) Walker, B. M. 編: "Handbook of Thermoplastic Elastomer" van Nostrand Reinhold Co., (1979).

12) Murtland, W. O.: Elastomerics, May, 19 (1982).

13) Legge, N. R.: Chemtech, Oct., 630 (1983).

14) Modern Plastics International: December, 34 (1983).

15）日ゴム協誌：本号 TPE 特集号 (1984)

16) 高沢茂治：ポリマーダイジェスト，1982・8，2 (1982).

17）青木潤次郎 : ibid 1982・3，43（1982）

18）寺西 丕：プラスチック，34（8），20(1983)

19) Byam, J. D., Ziegel, K. D.: European Rubber J, Nov 27 (1981).

20) Monroe, C. M.: Kautschuk u. Gummi Kunstoffe, 35, 661 (1982).

21）原田都弘：プラスチックス，30(3), 11 (1979)

22) Shäfer H. O.: Kautschuk u. Gummi Kunstoffe, 36, 180 (1983).

23) Fithian, L. E.: J. Elastomers \& Plast., 14, (Oct.) 222 (1982)

24) Brifish: Plast. \& Rubber, Jan., 25 (1983).

25) Stemper, J.: Kautschuk u. Gummi Kunstoffe, 37(1), 13 (1984)

26） 三宅 彰: プラスチックス，35(1) 137 (1984)

27) Pirret, O. J.: Europ. Rubber J., (1), 11 (1979).

28) Thorstad, J.: ibid, (11) 17 (1979)

29) Modern Plastics International: June, 12 (1981)

30) 奥谷栄太郎：高分子, 29, (10), 752 (1980)

31) Trexler, H. E.: SPE 39th Annual Technical Conference and Exhibition, 1981.

32）片山諴三：プラスチックエージ，29，(10） 82
(1983)

33) Holdern, G.: ACS Rubber division, May 4 (1982)

34）化学工業日報：57年10月18日

35) Modern Plastics International: 12(5) 96 (1982).

36) Sperling, L. H.: J. Polymer Sci, Macromol. Rev., 12 (1977).

37) Holden, G.: ACS Ruber division, May 4 (1982).

38) Baker, L.: IISRP 24th Meeting, Kyoto (1983).

39) Chem. Week: Feb. 2, 58 (1983).

40）竹內安正：日ゴム協誌，52，481(1979)

41) 藤本邦彦: ibid, 52, (5), 281 (1979)

42) Wood, A. S.: Modern Plastics. September, 70 (1978)

43) 竹内 正: プラスチックス, 32(7) 51 (1981)

44) 林 裕久：日経エレクトロニクス，187，52(1978)

45）山本 襄, 山下岩男: 第 5 バイオマテリアル学会 (1983)

46）加藤正雄，山辺正顕：高分子学会予稿集，31,271 (1982)

47) P. M. Van der Velder: J. Appl. Polymer Sci., 21, 1445 (1977)

48) Plasti world: Feb., 11 (1983).

49) 岡田 司: プラスチックス, 34(8) 36 (1983)

50) 葛岡 温: 化学, 32,638(1977)

51) Bigg, A. et al.: Kautsch u. Gummi Kunstoffe, 34(5) 349 (1981)

52）中川凱夫：プラスチックスエージ，25（5）83 (1979)

53) Elliot, D. J. : 天然ゴム, 13, ( 2 ) (1981)

54) Bristow, G. M.: NR Technol., 12, 36 (1981)

55) 山田準吉：日ゴム協誌，54,33(1981)

56) Plastics Technology: March, 17 (1981).

57) Bateman, L. R.: Adhesive Age, 24(11), 50 (1981).

58) Yamashita, S.: IISRP, 24th Meeting, Kyoto (1983).

59）山路 功, 石田紘靖: 日本ゴム協会, 第49回総会 研究発表会 (1982)

60）旭化成：特公開昭56-118405，118447.

61) ПHEЕ, A.: Vysokomol., Soed., Ser. A, 23(4), $843(1981)$

62) Siegfried, D. L.: J. Appl. Polymer Sci, 26, (1), 177 (1981).

63) Sharkey, W. H.: SPE, 39th ANTEC, 417 (1981).

64) Dreyfuss, P., Fetters, L. J : RCT, 53, 728 (1980)

65) Lorerrz, O.: Angew. Marromol. Chem. 72, 115 (1978).

66) U. S. P.: 4,252, $704(1981)$

67) Hsine, T.:J. Appl. Polymer Sci., 25, 1715 (1980).

68) Saam, J. C.: J. Inst., Rubber Ind., 7(2) 69 (1973)

69) Noshsay, A.: J. Polymer Sci., A-1,9(11) 3174 (1971).

70) Kira, K.: 4th Meeting, Japan Biomaterials (1982).

71 USP: $4,256,861$ (1981).

72) Bigg, A.: Kautsch u. Gummi Kunstoffe, 34(5), 349 (1981).

73) McKnight, W. J.: ACS Rubber division, 123rd Meeting, Tronto (1983).

74) Hertler, W. R., Webster, O. W.: ACS Rubber division, 125th Meeting, Indianapolis (1984).

75）重村義紀，寺島啓治：プラスチック，34（8）47 (1983)

76) 建元正祥；プラスチック，34（8）66（1983)

77) ゴム化学新聞：1982年10月5日。

78) Auchter, J. F,: Automotive Elartomer \& Design, Sept., 32 (1983).

79）青木恂次郎：合成樹脂，29（8）2（1983）

80）たとえばプラスチックハンドブック：朝倉書店 (1969) 